Ileana Nicoleta Sălcudean

Faculty of Theatre and Television, Babes-Bolyai University

Cluj-Napoca, Romania

nicoleta.salcudean@gmail.com

\title{
THE TRANSNATIONAL IDENTITY OF EUROPEAN FILM FESTIVAL. NEW MEDIA AND CULTURAL BRANDING EMPLOYED AT TRANSILVANIA INTERNATIONAL FILM FESTIVAL
}

\section{Recommended Citation}

Sălcudean, Ileana Nicoleta. "The Transnational Identity of European Film Festival. New Media and Cultural Branding Employed at Transilvania International Film Festival". Metacritic Journal for Comparative Studies and Theory 3.1 (2017): https://doi.org/10.24193/mjcst.2017.3.11

\begin{abstract}
European film festival venues are explored in their relation to transnationalism, a "supranational sphere", as well as with political and economic implications (Acciari, 2014). The international film festivals are seen as cosmopolitan spaces (Chan 2011, 253), yet, the new morphology of film festivals perceived as "public spheres" or as new objects of historical research - bring a new light on film festivals and the theory of culture and visual discourse, especially with the new reconfiguration of festivals in Europe, the insertion of new technologies and new opportunities to explore local identity. The article examines the cultural determinants and the new vocabulary of visual discourse, exploring the implied questions regarding national identity $v$ s. European identity, and the possibility of building a cultural city/ country branding. With a case study on the Transilvania International Film Festival, I attempt an inquiry of three interconnected aspects employed in exploring film festivals and their transnational dimension: the impact of the new media on the audience, the challenge of identity and the possibility to create a city/ country branding.
\end{abstract}

Key words: film festival, transnational identity, cultural determinants, country branding. 
Acknowledgment: This work was supported by a grant offered by Babeș-Bolyai University, Cluj-Napoca - project number GTC 2016/ 31813.

\section{Introduction}

The visual language of the new visual culture with the transgression of boundaries and the obsession for cultural determinants triggers inquiries regarding the dominance of the Western visual discourse versus the Eastern visual discourse. Visual language is culturally coloured, even with "regional and social variation". The unity in Western visual design "derives from the global power of the Western mass-media and culture industries, and their technologies" (Kress and van Leeuwen 3-4). Are the Western visual communication traits integrated in or influencing different cultures? How are the new technologies and globalization influencing the visual discourse, on the one hand, and how are they engaging with visual culture, on the other hand? How is new media altering the new identity of the public? Though we are very much intrigued and mesmerized by this visual discourse, some questions need to be asked with regard to other cultures and traditions ${ }^{1}$.

In the past, visual culture was controlled by geographic boundaries, funding and language. Today, the borders are open (Smith-Shank vii). "Overlapping meanings of visual culture signs, within the context of a social and cultural aesthetic are often cause for cognitive dissonance" (Smith-Shank viii). An average European now spends more than 30 hours per week using the Internet or watching TV. In the last decade, digital incomes recorded an increase in the creative sector, adding 30 billion in revenue between 2001 and 2011, and the trend is still increasing (Creating growth 22). Competition is a good platform for creativity and growth.

Are film festivals part of a European agenda or are they developing according to the societal needs and reflecting them? Could we consider them an

\footnotetext{
1 "In a recent article Andrea Noble discusses the current turn to visual culture in relation to Latin American studies ('Notes '). While she welcomes the new academic attention to the visual, which is held to correspond to shifts in the nature of a society that has moved from the text to the image, she also questions the validity of this general debate for the specific case of Latin America. Noble argues that it is only if the textual is restricted to alphabetical writing that it can be contrasted with the visual. In Amerindian cultures that used painted signs or knotted strings as forms of notation, the distinction cannot hold" (Smith 1).
} 
expression of European identity? (European Arts Festivals 6) Being promoted as performance of culture in the public domain (Alexander et al. 2006), film festivals launched debates about representability (gender, ethnic, age groups) and European identity (with emphasis on diversity and tolerance). (European Arts Festivals 6).

Yet, European cinema may be discussed in terms of representation and cultural identity as a consequence of the senescent notions of auterism and national cinemas. Within this paradigm, film festivals tend to be perceived, on the one hand, as

typically postmodern phenomena, in their auto reflexive and self-referential dimensions, but also quite rich in mythic resonance with their performative tautologies. On the other hand, they are clearly a product also of globalization and the post-Fordist phase of the so-called creative industries and experience economies, where festivals seek to realize the time and location advantages we also know from tourism and the heritage industry, but now for other purposes. These purposes have yet to be more clearly defined. For the European cinema, they are particularly uncertain and likely to be regarded with scepticism if not cynicism, if we insist on keeping the first-order values of art, auteur, and national cinema intact as our guiding principles. (Elsaesser 103)

Multiculturalism as a well-trade notion became also scrutinized together with

endless debates over integration and assimilation versus cultural autonomy and separate development regarding ethnic or religious minorities within the nationstates in Western Europe seem mostly to have ended in intellectual stalemate, while sapping the energies of the public debates as well as the political decision making processes: fatigue, helplessness and frustration have become difficult to distinguish from each other, with the result that political apathy and populist demagogy are now the two extremes that touch each other in the debates on minorities in virtually every country of Western Europe. The European Union, for its part, has practically banned both the terms cultural identity and multi-culturalism from its vocabulary, preferring to speak of multi-cultural competence as the desirable goal, when trying to renew the social contract, while progressive cultural institutions in the memberstates now re-label themselves as promoting (and institutionalizing) diversity (Trifonova 49-50). 
Identity in transnational Europe will be approached in relation to cinema, mainly film festivals and the way they use and integrate new media, as well as their attempt to create a city/ cultural branding. As we are witnessing a "re-mapping of global cinema in accordance with regionalist discourses" (Iordanova 2), it is inevitable to consider the international patterns, hence acknowledging the distinct traits of East Central European cinema, as a direct focus of our research. Exploring the cultural determinants of our region we are at the same time engaging with the new vocabulary of the visual discourse and the way it translates in our context.

Therefore, for this endeavour, I attempt an inquiry of three interconnected aspects employed in exploring film festivals and their transnational dimension: the impact of the new media on the audience, the challenge of identity, and the possibility to create a city/ country branding. All these aspects and inquiries are analysed in a case study on Transilvania International Film Festival, based on media analysis and interviews.

\section{European Identity: Identity Crisis and Cinema Resolution}

The European cultural identity (Western) was designed ethnocentric and antietnocentrist (Todorova 294). Fuery stresses the need to study new media in terms of cultural studies and critical theory, addressing concepts such as discourse and power (Foucault, The Archaeology of Knowledge) (Fuery 4).

The new Europe is the old Europe of geopolitics. It once more matters-as it hardly did in the time of the Cold War, when two power-blocks divided the continent and dominated its peripheries, and international was the natural adjective of dissidence and counter-culture-where you are from (as an individual) and what your geographical location is (as a country, a nation, a people). Europe is rediscovering its roots, its regions, its local customs, ethnic identities, religious, cultural and culinary specifics" (Trifonova 47).

And that might be the reason why identity discourses gain traction within the European Union, both as an exultance and a cry of help. The gesture of national cinemas reflects the display of their uniqueness and their struggles. The identity crisis today may derive from the algorithm failure that a united economic market leads to a unified cultural identity, which in turn leads to a sense of 
citizenship; restructured markets led to increased costs and fragmentation of identity (Nowell-Smith and Ricci 21, 29)².

The European identity dilemma is not only related to Europe but also the United States:

There is reason to debate that there is such a thing as a European cinema, much less a European culture in any canonical sense. There is reason to denounce the dangers of invoking these legacies in the name of identity politics. But movements to cultivate a vast cultural space in Europe in which to experiment with cultural diversity and innovation are sound, intriguing and worthy of respect. (Nowell-Smith and Ricci 30-31)

Trifonova is talking of the "double occupancy" of Europe with regard to its recent history as well as the consequences of colonialism as being "at once tragic, comic and utopian”. The last developments regarding EU might be viewed more as a counterpart of the idea that the digital crisis of cinema can contribute to the present crisis of $\mathrm{EU}$ in terms of communication and representation:

My first answer is: it can contribute its own crisis of representation. Cinema's current crisis of representation is usually located in the so-called loss of indexicality of the photographic image, by the transition to the post-photographic or digital image. I see digitization more as a way of thinking productively about rupture than as the determining factor of rupture. And when I suggest that real location, fantasy space, performative place cinema should contribute its crisis of representation, it is in the sense of rupture as indicated above: maybe the digital revolution is contemporary cinema's equivalent of the Boston Tea Party and the "off-with-hishead" moment in the history of visual representation! (Trifonova 51-55).

The reverse question is: could cinema contribute to solve this crisis as well?

Monia Acciari believes that contrary to Iordanova's assumption that film festivals have a certain centralizing structure, they do offer a

"rhizomatic connection", a "fluidity" that "destabilizes the idea of multiculturalism as a fragmented social phenomenon and empowers the festival to be a cultural force

\footnotetext{
2 "Counter-cinema notion of Godard, implied a film-politics that would challenge the economic supremacy of Hollywood, its monopolistic distribution and exhibition system in the countries of Europe, but also in the Third World" (Elseasser, 464-465).
} 
able to establish a conceptual framework that embraces nomadism and fluidity, both expressions of a rhizomatic society, thus giving rise to an emergent series of readings.... In so doing, they facilitate the understanding of entertainment spaces as flexible in lieu of permanent (or solid) arrangements (Acciari 23).

Even with these fluid borders that allow the exchange of ideas and models, the homage of the Western culture remains noticeable. The new iconography and semiotics 3 of festivals trespass national borders, yet, the questions remains regarding the originality and novelty of their attempt. Thomas Elsaesser considers that cinephilia is describing a map in Europe, connecting cities based on film festivals and urban interests. Might be similar to what Elsaesser describes as cinephilia in Paris,

where the original cinephiles of the post-war period divided up the city's movie theatres the way gangs divided up Chicago during prohibition: gathering at the MacMahon close to the Arc de Triomphe, at the Studio des Ursulines in the é or at La Pagode, near the Hotel des Invalides, each cinema hosted a clan or a tribe that was fiercely hostile to the others (De Valck 30)4.

\section{New Media and the Reconfiguration of the Public}

One of the benefits of making art in the early days of new media was that new media operated outside of the cultural mainstream. As a result, exterior interests and pressures were few and the exigencies of the work itself were free to drive the creative process. But this fecund seclusion also had its drawbacks, for there were few opportunities to exhibit works produced and even fewer occasions on which anything intelligible was written about them (Manovich and Kratky 4).

New technology is a means to transfer power to the average individual.

\footnotetext{
3 "In their similarities, iconography and semiotics are both concerned with what objects mean, consider the significance of their historical development, and question how objects acquired their meaning. Fundamentally, both embrace concepts found in anthropology, where works of art are seen as cultural systems; as objects that define social relationships, sustain social rules and strengthen social values" (Smith-Shank, 2004, 89).

4 "Cinephilia, in other words, has reincarnated itself, by dis-embodying itself. But what it has also achieved is that it has un-Frenched itself, or rather, it has taken the French (term) into a new ontology of belief, suspension of disbelief, and memory: possibly, probably against the will of the "happy few," but hopefully, once more for the benefit of many" (De Valck 41).
} 
Hypermedia ${ }^{5}$ software is meant to serve two different purposes. Firstly, it should allow authors to build, quickly and simply, associative links between different media. Secondly, it should allow readers to traverse these links quickly by moving through the associative structure ${ }^{6}$. (Crawford and Turton 3014).

Even the very idea of change can be instrumentalised in a negative way again, sometimes in the form of control, as, for example, the case of new media in relation to the concept of Marxist hegemony (Fuery 134).7

This diversification of new media and incessant changes related to the advancement of technology can be subversive. Examples of illegal dissemination of narratives on the Internet (with topics related to sexuality or terrorism), acts/ phenomena as happy slapping, cyber-stalking etc. may be relevant (Fuery 143). New technologies also relaunch the question regarding communication and art. The borders seem to decrease their stern limitations.

Anthropologists and programme-makers are communicators whereas film-makers are artists. Anthropologists share with programme-makers the compulsion to explain, film-makers, on the other hand, share with programme-makers the compulsion to entertain (Crawford and Turton 261).

At the level of cultural discourse, new technologies are reflected in consumerist films either as possibilities of survival or as a cultural paranoia (examples of films: Hackers, The Bourne Identity, Blow Out, Enemy of the State). ${ }^{8}$

These negative characteristics of the new media as part of the cultural order and as a denial of it at the same time are seen by Fuery as a carnival's attribute: "The carnivalesque aspect of new media has a further level to it - the interrelationship between power and paranoia" (Fuery 144).9 The author does not

\footnotetext{
5 Hypermedia is a relatively recent concept derived from the term hypertext hybridized with multimedia and refers to a computer program or series of programs that manage media. (Crawford and Turton 261).

${ }^{6}$ In many programmes, the distinction between author and reader is deleted - readers have editing rights.

7 "The term audience autonomy in this case refers to how contemporary characteristics of the media environment, ranging from interactivity to mobility to on-demand functionality to the increased capacity for user-generated content, all serve to enhance the extent to which audiences have control over the process of media consumption" (Napoli Introduction).

8 "Representations of new technologies as boon or catastrophe are both part of the hegemonic discourse that works through the effects of new media" (Fuery 143).

9 "The purpose of new media becomes disruptive and socially cohesive at the same time. It sustains the long traditions of the carnivalesque, and yet is also part of the dominant and mainstream cultural order" (Fuery 145). 
THE TRANSNATIONAL IDENTITY OF EUROPEAN FILM FESTIVAL

address new media as a "digitalization of the old media", but as a "cultural superstructure - that is, informing and influencing processes and relationships beyond itself and across heterogeneous forums" (Fuery 1).

We cannot discuss the evolution of media, without understanding the evolution of the public (Napoli Introduction). In Napoli's view, it is a public institution. Migration has been an important factor for the spread of new media. Mieke sees migration as a celebration of "qualifier migratory", an attempt to bring together memories from countries and communities of origin (Bal and HernándezNavarro 9-10). Identity becomes flexible, new media is changing the boundaries: "our lives, relationships, memories, fantasies, desires, also flow across media channels" (Jenkins 17).

In the East-Central European cinema, migration had a different connotation during the Communism (Iordanova 38-41), mainly political, and we can include under migration the "exilic" cinema as well. Cinema can redefine the condition of being European

not mirroring the other in mis-cognition and endless deferrals of self-identity, but enabling the other to interfere in my own mirror image. That, it seems to me, is the best, but also perhaps the most difficult way of living our hyphenated and always already occupied identities. (Trifonova 61)

The identity of the audience is also stratified into local, international (circuit festival fans) and professional audiences. "The films' attention to recognizable geographical places and stereotypical historical periods thus begin to echo Hollywood's ability to produce open texts that speak to a diversity of publics, while broadly adhering to the format of classical narrative" (Film Festival Networks 8283). Film festivals are creating a complex universe of networks at the micro-level, but also they connect with other festivals at a macro-level (Film Festival Networks 103).

\section{Festival Space: Local, National, Transnational}

In the festival different elements are drawn together from different cultures, including global culture. In this sense the festival differs from the cultural form of 
the exhibition in that it is based on hybridisation, cross-fertilisation and mutual borrowing (European Arts Festivals 6) ${ }^{10}$.

How do we envision film festival as local, national or transnational spaces? Film festivals promote image-culture (Nichols 68-85), while transcending the borders into the "supranational sphere" (Hagener, Malte 283-305). This dance between local and international is approached in relation to economics and cultural policies. ${ }^{11}$ The European agenda promoting awareness, social inclusion and cultural diversity is well mirrored in the cultural objectives of many European countries. Yet, is the potential to add value and set multiple agendas of film festivals (De Valk and Hagener 27-44) a corollary of the European agenda? European Arts Festivals. Strengthening Cultural Diversity is a monograph based on the research carried out by the Euro-Festival project 'Arts Festivals and the European Public Culture' supported by the Seventh Research Framework Programme of the European Union and specifically the latter's 'Social Sciences and Humanities' (SSH) Programme. The aim of the project was "to examine the role of arts festivals as sites of trans-national identifications and democratic debate" (European Arts Festivals 6). The Euro-Festival project addresses film festivals beyond the cultural studies approach of the urban dimension and identity, the political sociology approach tackling the perspective of the public sphere, yet neglecting the artistic dimension, moving towards cultural policy (McGuigan 2004), using the term of the aesthetic public culture (Chaney 2002; Delanty, Giorgi and Sassatelli 2011).

Contemporary European arts festivals are European in being located in Europe; and by addressing issues relating to diversity, human rights, openness and democracy that are at the core of European values. But Europe (as in the European Union), like the nation-state, is often a suspect category as representing specific vested interests. The internationalism of festivals is a far more important category both ideationally

10 "Internationally or transnationally, each national cinema used to have a particular generic function: a French, Swedish or a New German film set different horizons of expectations for audiences, but which are inverse mirrors to the genre expectations suggested by a Hollywood Western, a science fiction film or a comedy, but which are equally essential a prerequisite for name recognition beyond the director: the firmer a national cinema's generic image, the better (for) the brand" (Elsaesser 466-467).

${ }^{11}$ While Cannes is always concerned with cinema as economic product... "is offering the ultimate network opportunity for the contemporary transnational cinema market" (Valck 120). 
and as an organizational format than Europe and this is unlikely to change in the near future (European Arts Festivals 69).

The important film festivals of Europe do not even have EU funding. Jérôme Segal views the festivals as a possible cinematic experience related to community, in a very fast growing individualist era: "In a time of growing individualism, epitomized, among else, by the development of so-called 'home cinemas', the desire to collectively experience live events is partly satisfied by festivals" (European Arts Festivals 38-40). His research proved that film festivals do not reflect the European identity so much, as they mostly prefer to be regarded as international, which might be interpreted also as a sort of cosmopolitanism. So, they show the local/ urban identity and the international aspiration, reflected also in the audiences that are having. That could engender city branding on the one hand, but also some disturbance for the locals; the solution could be to make the films available to a larger local audience. It is well known the initiative of Dieter Kosslick, the Berlinale director in 2001, who organized 'Berlinale goes Kiez', which created a special awareness throughout the city, and established a new world record of 299478 tickets sold during the eleven days of the 2010 festival (European Arts Festivals 42-43).

The network with international artists and the impact on the local artists as well as the local public could also be considered as part of the synergy that film festivals are creating. They are multidisciplinary art celebrations, as they encompass other dimensions as well. More and more, they incorporate other artistic events, educational endeavours and social platforms and they promote other creative industries. ${ }^{12}$ Festival circuit 13 in Europe is considered by Elseasser to be the

\footnotetext{
12 "This is also reflected in an equally multifaceted mix of venues, audiences and aims. The mixing of artistic and social activities put this type of contemporary artistic festival on a continuum with earlier, community-based festivals. So, whereas most festivals often actually stage events of more than one discipline (e.g. literature festivals often have a cinema section, music festivals include visual arts exhibitions, etc.), in mixed arts festivals no single genre dominates and defines the festival as a whole. As a result, many of these mixed-arts festivals define themselves by referring to the place that hosts them, most often a town or city. The urban dimension is therefore a defining feature of most mixed arts festivals. Urban festivals are not simply festivals happening in cities but festivals of the cities; they are multi-dimensional, complex events held together by their drawing on urban identity, urban lifestyles and values. This synergistic relationship between the festival and the city works, we might say, like a chemical reaction" (European Arts Festivals. Strengthening Cultural Diversity, p. 48 - Monica Sassatelli and Gerard Delanty).
} 
key force and power grid in the film business, with wide-reaching consequences for the respective functioning of the other elements (authorship, production, exhibition, cultural prestige and recognition) pertaining to the cinema and to film culture (Film Festival Networks 82-83).

13 Caravans of films start in Berlin (mid-Feb) and really acquires their contours and currency only in May ("Springtime in Cannes"), to be carried to Locarno (July) and over into Venice (early September), thence to be taken up by Toronto (late September), London (October/November), Sundance (mid-January) and Rotterdam (January/February). 


\section{Film Festivals and City/ Country Branding}

Film festivals are viewed as promoters of tourism and city branding, attracting even capital investment (Crespi Valbona/Richards 2007, Derrett, 2000, 2003).

Branding the city and branding the festival go hand in hand: the festival is seen as fundamental for the city profile, and vice versa, festivals and their host cities are linked by a symbolic (rather than causal) relationship. For instance, landmark buildings as festival main venues or headquarters are important as they contribute to the profile of the organization. The importance of this branding component for a cultural sociology of festivals is difficult to grasp with a superficial notion of citybranding that emphasizes the exploitation of a city's (and festival's) identity in terms of consolidated traditions or heritage... An interesting way these festivals are increasingly like brands is in their use of themes. These are increasingly used as framing devices, as verbal logos that work both as an organizational and as an artistic device, allowing however a substantial degree of variation and interpretation (European Arts Festivals 52-53).

Others, like Loist and de Valck, consider that

at film festivals the connection between the festival's content and regional distinctiveness of its location, however, is less obvious. Most programs have a strong international character and attract cosmopolitan visitors that want to celebrate and consume world/art cinema. (Loist, S., \& de Valck, M, 2010)

Whether film festivals are considered to be "public spheres" (Stringer 138) or cosmopolitan spaces (Chan 253), they are nevertheless "inherently linked to societal and cultural concerns" (Elsaesser 27). Also Elseasser brings into discussion the broader audience in cinema, but mainly in relation to the postnational concept (as a second order category) and the films without reference to place or region or nation or past (Film Festival Networks 82-83). There is a very dynamic relation between the city, the festival and its audiences, as there are many actors involved in this network. The examples of the A type festivals Cannes, Venice, Berlinale, show the dynamics between the international scene and the local 
scene. Cannes Film Festival is depending on "Hollywood's film business" but at the same time is trying to fight its hegemony (Valck 121).

Film festivals have a capacity for self-preservation.

In the 1970s, they responded to youthful rebellions worldwide and supported young film talent and political struggles. In the $21^{\text {st }}$ century, they close professional sponsorship deals and seek industrial partnerships in order to continue to grow and to remain competitive. (Valck 207)

There was a shift towards independent programming after 1968: new alternative sessions, adapting to the needs of the audience. The historical perspective tackles on the political decisions vs. the cultural decision and the relation between them. City branding could be perceived in terms of discovering/rediscovering identity.

\section{Romania. Transilvania Film Festival}

If we consider the main dilemmas of the East-Central Europe regarding history, ethics and social order rendered as well as the core themes of the EastCentral European film "history, memory and morality" (Iordanova 43-45), the path of Romanian cultural struggles are well integrated into the picture. In previous research on cultural policies (Sălcudean 2016), I observed that nationalism and the extreme tendencies - either clinging to the past or uncritically takeover of western patterns - are obstacles in the development process. The Romanian culture has crossed different phases in the last decade. It went from the communist censorship, passed the troubled period after the revolution, to the preEU accession and then post-accession when cultural policies had as a goal to follow European directive of culture. Opening the borders, partnerships and networks can channel nationalism in creating a country branding culture. The main directions represented in the Romanian cultural policies are: heritage, creativity and cultural diversity, religion, finance and development. The model remains UK, where it was established a Centre for Promotion of Film, Digital Media and New Technologies (Centre for Research and Consultancy on Culture 22).

After the 90s, film festivals proved that art cinema can be "economically viable" (Valck, 2007, 209). Transilvania Film Festival managed to reach the $16^{\text {th }}$ 
edition this year. ${ }^{14}$ Transilvania IFF is a member of the Alliance of Central and Eastern European Film Festivals (CENTEAST), supported by the Creative Europe MEDIA Programme and in 2011, Transilvania IFF was accredited by the FIAPF, which places it among the 40 most important festivals in the world. ${ }^{15}$ We recognize with Transilvania IFF the three historical phases of film festivals - from being "showcases of national cinemas... to operate both as protectors of the cinematic art and as facilitators of the film industries... to becoming professionalized and institutionalized" (Valck 19-20). As a result of the research with regard to the Romanian cultural policies, we found that the opening to the outside, partnerships and networking, can channel nationalism in creating a cultural country branding. In the current development plan we noticed as a priority "a new branding strategy, with focus on Eastern Europe and the Balkans, the plan outlined by the Ministry of Culture in collaboration with the Romanian Cultural Institute."16 We conducted a research on the role of film festivals in creating a cultural branding, as well as the way in which Transilvania IFF becomes a reference point in this direction. Could we consider a transnational dimension of Transilvania IFF and to what extend is Transilvania IFF contributing to the cultural country/ city branding? What is the influence of the Transylvanian context and Romanian identity? What role does new media play with regard to the festival?

I conducted 16 interviews with different actors involved in TIFF: managers, volunteers, participants in the competitions (age ranging from 22 to 46 years old). The analysis of the interviews conveyed that Transilvania IFF reflects well the Romanian identity especially by stressing especially on Romanian films and Romanian directors, and it became a Romanian brand as it is visible in the financial support for the organization of the festival and the great number of visitors. Others consider the interest of the Romanian public for the new Romanian film somewhat artificial as the cinema halls are full during the festival, yet few people are attending when the films are actually launched in the cinemas. That is considered a paradox. Transilvania IFF has surpassed the Romanian

14 There are other 18 registered festivals in Romania ( 4 in Cluj-Napoca).

15 Transilvania IFF is rapidly growing, becoming a facilitator for film industry, but also showing efficient management. The 2016 edition was a record: 79 ooo tickets sold; 248 selected films from 64 countries; 400 screenings; 1100 attending filmmakers, actors, distributors, sales agents, producers, and festival programmers; 250 attending journalists; 330 volunteers.

${ }^{16}$ Compendium, Cultural Policies and Trends in Europe, p. 8, 
borders, becoming truly an international festival, creating a specific atmosphere that is part of the trademark. Also, many consider that the fact that the festival is audience-friendly managed to create this friendly environment and relaxed vibe and re-affirm the traditional hospitality. "The energy of the festival is overwhelming and catalytic and this is what I appreciate most at this festival" (Cristian Hordilă, festival manager).

The strategy of branding is taking into consideration both aspects: building on the known symbols, but bringing something new and exciting every year. The different persons interviewed agreed that Transilvania IFF has a great contribution for the Romanian culture, and inevitably for the city of Cluj-Napoca as well. The exotic image of Romania (and Transylvania even more) triggers a certain fascination for the foreigners, and as they come to the festival, they have the opportunity to discover the land of Romania and test their ideas about the country. Some persons consider that Transilvania IFF is the main source of cultural branding in Romania, after the musical events that contribute massively to create a good image of our country (e.g. George Enescu International Festival from Bucharest). Yet, this branding is built over time, there are a lot of resources involved and the network existent in creative industries has a great contribution. Film represents the "best product for international cultural trade in Romania" (Mihai Fulger, film analyst, member of the jury), even if the Romanian cinema continues to be the Cinderella of arts (literature-music-painting) as Alex. Leo Şerban observed a century ago. Ligia Soare (film department Transilvania IFF) underlines the fact that the Romanian new films are drawing attention inside the country based on international recognition (awards and prizes won abroad). Transilvania IFF is becoming such a recognized symbol in Romania as well, also based on the echo abroad (as the festival is well received in the European context). The festival has a lot in common with other European festivals; from this point of view, some consider that the branding is not well perceived and Transilvania IFF is still improving its image to be more distinct and recognizable. Also, the festival is well connected to the European and international cinematic trends. Regarding the configuration of visual trends in Romania, some consider that other festivals (A category festivals) may have a greater role. Oana Giurgiu (executive director, Transilvania IFF) considers that the film-makers that are present at the festival have the chance of networking with other professionals and encounter the current 208 
visual trends and cinematic perspectives. "Film has long ago exceeded the art border, becoming accessible to anybody who wants to communicate through images". Also, the large display of films (different genres and sub-genres) that are selected in the festival promote the new visual trends and reflect the use of different technologies (Anca Macoviciuc, accreditation coordinator Transilvania IFF, Blog coordinator). The films promoted during the festival become a must-see, they are endorsed by the festival (Alexandra Ghejan, volunteer 5 editions).

The festival has and will influence the audience... it enlarges the horizon of the young cultural entrepreneurs, in the film industry as well... contributes to the cultural-artistic construction in Romania, though there are still many more things to be done in this area (Hordilă).

The name of the festival might not be the best choice, as there are other international festivals that share the same acronym (Toronto Film Festival, Tokyo International Film Festival, Thessaloniki International Film Festival), but there are two important factors that provide the platform for country branding: the organization of the festival and the well targeted promotion (including word-ofmouth marketing) (Fulger). It is visible that there is an efficient strategy behind (Cristi Mărculescu, selector Transilvania IFF, editor Aperitiff). The festival is better perceived abroad that in the country (Alina Grad, subtitling volunteer coordinator). For guests, the branding created is not necessarily perceived as a goal, but rather an organic development as the organizers strived to organize a successful festival, the branding came by default (Andrei Dăscălescu, director, guest at Transilvania IFF). Cristian Hordilă confirms that Transilvania IFF has a solid concept, but the brand so far was developing naturally, as the festival matured, and without a special attempt towards this target. Yet, some very distinct features are transmitted by the organizers as they are leaving their own signature on the festival.

New media is indeed facilitating the access of many to this festival, providing both national and international audience. The festival is cleverly promoted online and it became a pole of the creative industries in Romania. Transilvania IFF is the first Romanian festival that adopted specialized software in the internal organization and the digital technology for marketing (Macoviciuc). Facebook is indeed a good tool for promoting the festival and for preserving the 
networking among different groups of interest, communication among different audiences. "Everything that is digital can be a good tool for improving the experience of the public. The technical department of the festival is taken over by IT specialists" (Hordilă).

Part of the core identity traits of Transilvania IFF are the focus on the new directors and film-makers, the section dedicated to horror short-movies and the special target for Romanian movies. The city branding is visible in connection to the other special events (concerts, exhibitions, workshops, social events etc.) organized in Cluj-Napoca, the unique locations and landscape. The organizers foster the relationships with the local government, as well as with the universities, museums or other cultural institutions from Cluj-Napoca (Hordilă). The mere fact that there is such an extensive number of volunteers involved in the organization of the festival reflects the impact and the atmosphere of the festival. The city is transformed during the festival, the presence of different booths or built structures, the logo of the festival, the online and off-line publicity (Grad) contribute to the new image of the city that is becoming the exciting context and promoter of the festival.

\section{Conclusions}

Film festivals have European roots (before the WWII), but have become global phenomena. Yet, they were inevitably influenced by Hollywood in a high culture $v s$. popular culture dispute; state-model (subsidized cinema) in Europe $v s$. studio-system (box-office cinema) in Hollywood; work or art of an auteur vs. entertainment involving stars; festival circuit in Europe vs. Academy Awards (Oscar night) of Hollywood (Valck 14-15). ${ }^{17}$ The transnational attribute of film festivals can be approached at the intersection of new media and new technologies, representations of identity and country/ city cultural branding.

Nowadays, new media is an ideology construct (Fuery 22). We could identify different levels of crisis: crisis of representation at the political level (sovereignty democracy and social contract), the aesthetical level (referentiality, the truth of image), and the communicational level (the role of belief, trust and

\footnotetext{
17 "International film festival circuit combines the local and the global, the city and the nation, and the space of the media with the place of the event in the network configuration..." (Valck 18).
} 
THE TRANSNATIONAL IDENTITY OF EUROPEAN FILM FESTIVAL

good faith). The core of this crisis is not in the digitization, nor in the post-colonial or post-Cold War, but rather in the change of thinking and understanding. Cinema has the privilege to reflect the crisis but maybe also to bring a solution.

That cinema is a privileged mode of communication and intersubjectivity, tracking the always already givenness of a historically and politically situated (and thus occupied) state of affairs, is due precisely to the fact that it has no ontological ground, if by that we mean the truthful representation or unmediated disclosure of reality (Trifonova 55-56).

The public sphere has become a media sphere. Thomas Elseasser mentions the "post-national" concept of the European cinema in the context of the EU mediating with legislative and economic measures in order to stimulate the audiovisual industries, mainly in connection to preservation of heritage and patrimony (Film Festival Networks 82-83). His division refers to three levels: national, regional and local. Also, there is a shift away from the too used category of nation and auteur as connected to Europe towards the global economy and the city (Valck 30).

The Romanian culture is deeply related to the perception of national identity, tradition, representation and politics. City branding could be perceived in terms of discovering/ rediscovering of identity. Nevertheless, the economic factor cannot be omitted in the festival - city - festival exchange. The impact of the local film industry, the promotion of national films, as well as the influence of the context are important factors. Yet, "contemporary filmmakers can become trapped in a cultural ghetto by becoming dependent upon subsidies and festival prestige" (Valck 208).

With the "new principle of trans-national sovereignty", almost a "new social contract" and a "post-identity thinking", EU helped us think more about nationhood (Trifonova 54-55). This is a good opportunity to examine more the binary: Western European cinema vs. Eastern European cinema, questioning the meaning of unity in diversity and exploring the credit of national $v s$. transnational attributes. Even more, festivals "frame the discourse of identity in relation to arts with particular attention to the local/ national/ supra-national and local/ global 
interfaces as well as the conundrum of difference (diversity) and similarity" (European Arts Festivals 7).

In previous research on cultural policies in Romania (Sălcudean 2016), we observed that the Romanian art is visible from two directions - from a traditional standard within the country and from an avant-garde direction, visible outside the country, criticized by insiders. Both, however, are dealing with challenges related to the national identity. We could distinguish on the one hand the labels used by those for which we define as others - as well as our own perception, on the other hand, then the negotiation process between the two and the new construction of identity that hybridise and then re-hybridise culture. In addition, another conclusion is that often the recognition outside the country in terms of cultural products means also the national recognition, not the other way around. That tendency is also verified in the Romanian cinema productions and film festivals. I conducted 16 interviews with different actors involved in TIFF: managers, volunteers, participants in the competitions (age ranging from 22 to 46 years old). The analysis of the interviews conveyed that Transilvania IFF reflects the Romanian identity while creating a strong identity itself. The festival brand and the city branding are interconnected and they are built organically, enhanced by the new media. The transnational attribute of the festival is an outcome of the identity-construction.

\section{References}

Acciari, Monia. "Film Festival and the rhythm of social inclusivity." Cinergie, vol. 6, 2014 . Chan, Felicia. "The international film festival and the making of a national cinema." Screen, vol. 52, no. 2, 2011.

De Valck, Marijke. Film Festivals: From European Geopolitics to Global Cinephilia. Amsterdam University Press, 2007.

Derrett, Ros. "Can Festivals Brand Community Cultural Development and Cultural Tourism Simultaneously?” Events Beyond 20oo: Setting the Agenda: Proceedings of Conference on Event Evaluation, Research and Education Sydney July 20oo, edited by John Allen, et al.. Australian Centre for Event Management, 2000. Derrett, Ros. "Festivals \& Regional Destinations: How Festivals Demonstrate a Sense of Community \& Place.” Rural Society, vol. 13, no. 1, 2003. 
THE TRANSNATIONAL IDENTITY OF EUROPEAN FILM FESTIVAL

Elsaesser, Thomas. Cinephilia and the Uses of Disenchantment, edited by Marijke De Valk and Malte Hagener, Amsterdam University Press, 2005.

Elsaesser, Thomas. "Film Festival Networks: The New Topographies of Cinema in Europe." European Cinema: Face to Face with Hollywood, Amsterdam University Press, 2005.

European Arts Festivals. Strengthening Cultural Diversity. European

Commission, Luxemburg, Publication Office of European Union, 2011 -

https://ec.europa.eu/research/social-sciences/pdf/policy_reviews/euro-festivalreport_en.pdf, accesed in December 2016.

Foucault, Michel. The Archeology of Knowkedge. Pantheon Books, New York, 1972.

Fuery, Kelly. New Media, Culture and Image. Palgrave Macmillan, USA, 2009. Jenkins, Henry. Convergence Culture: Where Old and New Media Collide. New York University Press, 2006.

Hagener, Malte. "Institutions of Film Culture: Festivals and Archives as Network Nodes." The Emergence of Film Culture: Knowledge Production, Institution Building, and the Fate of the Avant-garde in Europe, 1919-1945, edited by Malte Hagener, New York, Berghahn, 2014.

Iordanova, Dina. Cinema of the Other Europe. The Industry and Artistry of East Central Film.Wallflower Press, 2003.

Kress, Gunther R., and Theo van Leeuwen. Reading Images: The Grammar of Visual Design. Psychology Press, 1996.

Loist, S., and M. de Valck, Film festivals/Film festival research: thematic, annotated bibliography, 2nd ed. Hamburg University, Institut für Germanistik II, 2010.

Napoli, M. Philip. Audience Evolution: New Technologies and the Transformation of Media Audiences. Columbia University Press, 2010.

Nichols, Bill. "Global Image Consumption in the Age of Late Capitalism." EastWest Film Journal, vol. 8, no.1, 1994.

Nowell-Smith, and S. Ricci, editors. Hollywood and Europe: Economics, Culture, National Identity 1945-95. BFI, 1998.

Sălcudean, Ileana Nicoleta. Cultural Policies: Between Bucharest and Brussels/ Politicile culturale: între București și Bruxelles. Risoprint, 2016. 
Smith, Paul Julian. Spanish Visual Culture. Cinema, Television, Internet. Manchester University Press, 2006.

Smith-Shank, and L. Deborah. Semiotics and Visual Culture: Sights, Signs, and Significance. National Art Education Association, 2004.

Stringer, Julian. "Global Cities and International Film Festival Economy." Cinema and the City: Film and Urban Societies in a Global Context, edited by Mark Shiel, and Tony Fitzmaurice. Blackwell, 2001.

Todorova, Maria. Balcanii şi balcanismul. Humanitas, 2000.

Trifonova, Temenuga, editor. "Real Location, Fantasy Space, Performative Place:

Double Occupancy and Mutual Interference in European Cinema.”, European Film Theory, Routledge, 2008. 